\title{
Arbetsglädje bland anställda anhörigvårdare
}

\author{
BENGT FURÅKER \& ANN-BRITT MOSSBERG
}

Anhörigvärd innebär att det i princip är samma person

som hela tiden är huvudansvarig för värdinsatsen.

I en tidigare artikel har visats att många kommunalt

anställda anhörigvairdare upplever bundenhet $i$ sitt arbete.

Här fokuseras i stället arbetets ljusare sidor - förekomsten

av glädje, stimulans och tillfredsställelse. Analysen ger vid handen att fränvaron av arbetsglädje bl. a. sammanhänger med upplevelsen av bundenhet. Samtidigt framkommer att

en annan faktor har en ännu mer avgörande betydelse: uppskattning från omgivningen. Det visar det sig också att

känslan av vara uppskattad är relaterad till hur anhörigvairdarnas ekonomiska situation förändrats sedan arbetet blev betalt.

I en tidigare artikel i Socialvetenskaplig tidskrift (Furåker och Mossberg 1997) har vi visat att kommunalt anställda anhörigvårdare i betydande utsträckning upplever bun-

Bengt Furåker är professor i sociologi vid Göteborgs universitet men har tidigare länge varit verksam både vid Lunds universitet och vid Umeå universitet. Hans forskning är främst inriktad på frågor kring arbetsmarknad, arbetsmarknadspolitik, välfärdsstat och offentlig sektor.

Ann-Britt Mossberg är doktorand vid sociologiska institutionen, Göteborgs universitet. Hon har tidigare framför allt studerat den offentliga äldreoch handikappomsorgen. denhet genom sitt vårdansvar. Detta har bl.a. att göra med ett av anhörigvårdens utmärkande drag, nämligen den höga graden av personkontinuitet. Vanligen är det samma person som hela tiden står för merparten av hjälpen och omsorgen. Personkontinuiteten har en rad uppenbara fördelar men också en påtaglig baksida: Anhörigvårdaren blir ofta starkt bunden i sitt arbete - ett förhållande som kan ha negativa konsekvenser för båda parter i vårdrelationen.

Det huvudsakliga empiriska underlaget till den nämnda artikeln, liksom till denna, 
härrör från en enkätundersökning genomförd år 1993 bland kommunalt anställda anhörigvårdare i Sverige (se vidare nedan). Respondenterna fick där bl.a. direkt ange hur ofta de som anhörigvårdare upplevde bundenhet. Ett annat spörsmål gällde om de ansåg sig kunna lämna vårdtagaren för längre eller kortare tid utan tillsyn. Vidare tillfrågades svarspersonerna om de någon gång kunde känna sig helt lediga och om de vid faktisk ledighet kunde koppla av utan att tänka på sin anhörige. För en klar majoritet av de anställda anhörigvårdarna måste svaren på var och en av dessa frågor tolkas som tecken på bundenhet.

Vi identifierade en rad faktorer av betydelse för upplevelsen av bundenhet. Denna visade sig inte minst starkt relaterad till hur lång veckoarbetstid man fick betalt för som anhörigvårdare och till förekomsten och behovet av samhällelig hjälp därutöver. Vår tolkning av dessa resultat är att vårdtyngd och bristande hjälp spelar en avgörande roll.

Bland respondenterna utgör kvinnorna en klar majoritet och vi fann vissa skillnader mellan könen i enkätsvaren. Dessa skillnader får nog i första hand tolkas som uttryck för att kvinnorna sköter personer som är mer vårdkrävande. Det uppträdde väl att märka inte några könsskillnader vad gäller anhörigvårdarnas förmåga att över huvud taget känna sig lediga och att vid ledighet koppla av utan att oroa sig för sin anhörige.

Det verkar vara anhörigvårdarna till vårdtagare med stort omsorgsbehov vilka av kommunerna får största antalet betalda arbetstimmar liksom. merparten av stödinsatserna vid sidan om. Men de kommunala insatserna förefaller ändå inte vara tillräckliga. Något mer än en femtedel av respon- denterna angav att de skulle behöva mer hjälp från samhällets sida. Det var också i hög grad dessa personer som uppgav sig vara bundna i sin situation.

Samtidigt finns det andra förhållanden som är betydelsefulla. Boende är ett sådant. Att bo ihop med den man vårdar innebär helt andra villkor än om man har separat bostad som kanske dessutom ligger på lite avstånd. En annan faktor är typ av relation. Somliga anställda anhörigvårdare är gifta med den de vårdar, andra är föräldrar eller barn till honom/henne och även andra relationer förekommer. Det framkom bl.a. att föräldrar som sköter barn i särskilt hög grad känner en bundenhet. I dessa fall rör det sig ofta om svårt handikappade barn, dvs. resultatet ligger i linje med vad som ovan sagts beträffande vårdtyngd.

Upplevelsen av bundenhet har också att göra med samspelet mellan anhörigvårdarna och deras vårdpersoner och omgivning. Det visade sig således vara betydelsefullt om vårdtagarna kräver att just anhörigvårdaren ska finnas till hands och om anhörigvårdarna har svårt både att säga nej till att hjälpa vårdpersonen med sådant som denne borde klara själv och att lita på andras hjälp och omsorg.

I denna artikel ska analysen föras ett steg vidare. Vi ska nu vända på perspektivet och koncentrera oss på resultat av positiv karaktär. Även om det är vanligt att anhörigvårdare upplever bundenhet rymmer deras arbete på samma gång väsentliga inslag av glädje, stimulans och tillfredsställelse. Att vara anhörigvårdare innebär ofta att leva i en verklighet med starka kontraster. Vi ska här ta fasta på några av denna verklighets ljusare sidor. Syftet är inte bara att beskriva dem 
utan också att undersöka vilka faktorer som ligger bakom. Den ursprungliga avsikten var att vi skulle se efter om och i vilken utsträckning upplevelsen av bundenhet inverkar på anhörigvårdarnas möjligheter att känna glädje i sitt arbete. Samtidigt fanns naturligtvis tanken att även undersöka betydelsen av andra faktorer. Efter hand visade sig speciellt en annan faktor vara väsentlig, nämligen känslan av uppskattning. Detta kommer att framgå närmare i den fortsatta framställningen.

Som ovan nämnts utgörs det empiriska underlaget här huvudsakligen av en enkät från 1993 bland kommunalt anställda anhörigvårdare. Efter ett slumpmässigt tvåstegsurval bland de då ca 6000 kommunalt betalda anhörigvårdarna i landet tillställdes ca 1400 personer i 86 kommuner en postenkät. Omkring 85 procent (1197 personer) skickade tillbaka frågeformuläret i besvarat skick. Av dessa var 85 procent kvinnor och 15 procent män. Vi har också gjort ett fyrtiotal intervjuer med anhörigvårdare och, när så har varit möjligt, med deras vårdpersoner. Intervjumaterialet har i denna och den föregående artikeln främst en idégenererande funktion.

\section{Arbetsglädje och arbetstillfredsställelse}

Sociologiska undersökningar har gång på gång visat att autonomi och beslutsutrymme i arbetet är avgörande faktorer bakom människors upplevelser av arbetsglädje och arbetstillfredsställelse (se t.ex. Blauner 1964; Gardell 1971, 1976; Herzberg m.fl. 1957; Korpi 1978, s. 142-147; Karasek och Theorell 1990; Vroom 1964). Ju mer själv- ständighet människor har i det de gör desto större verkar chansen vara att de också ska kunna uppleva arbetsglädje.

Många av de studier som gjorts kring arbetsglädje gäller industriarbete. Sådana jobb innebär inte sällan snäva ramar t.ex. vad gäller rörelsefrihet på arbetsplatsen, möjligheter att bestämma arbetstakten själv (den kan vara maskinstyrd) och möjligheter att planera eller lägga upp sitt arbete själv. Den typ av verksamhet vi här studerar befinner sig långt från industrins värld. Medan industriarbete i stor utsträckning avser relationer mellan människor och ting handlar vård och omsorg i stället primärt om relationer mellan individer. Dessa kommer vanligen varandra mycket nära i vårdsituationen (se t.ex. Eliasson m.fl. 1984; Eliasson 1992; Topor 1988).

En del forskning har dock gjort gällande att organisationen av vården och omsorgen ibland getts industriliknande former. I en avhandling redovisas tre olika organisationsvarianter inom hemtjänsten varav en närmast hade löpande-bandskaraktär (Szebehely 1995). Den senare modellen bedömdes ha en rad negativa konsekvenser både för hjälptagarna och för personalen. Även för sjukvårdens del har man identifierat karakteristika som hänför sig till industriella organisationsprinciper (Gardell och Gustafsson 1979; Evertsson 1995).

Samtidigt har den forskning som finns om arbete inom vården ofta framhållit att personalen är engagerad och motiverad (se t.ex. Aronsson m.fl. 1995; Eliasson m.fl. 1984; Eliasson 1996; Orban 1995; Szebehely 1995; Topor 1988). Detta sammanhänger med att vård- och omsorgsarbete är arbete med människor, men det är inte oväsentligt 
att de anställda vanligen också - framför allt inom hemtjänsten - har mer rörelsefrihet och självständighet än vad som förekommer $i$ industriarbete. Vid jämförelser mellan informell och formell vård framhålls ibland att den förra typen innebär sämre arbetsvillkor, bl.a. därför att vårdgivarna arbetar isolerat och saknar arbetskamrater. En positiv sida anses vara att det inte förekommer någon arbetsdelning utan man är sin egen chef och kan själv organisera sin verksamhet (Ungerson 1990, s. 26-27).

Vad som nu sagts behöver emellertid inte betyda att det saknas paralleller mellan industriarbete och anhörigvård. Uppenbarligen upplever anhörigvårdare ofta begränsningar i fråga om rörelsefrihet och möjligheter att planera sitt arbete och disponera sin tid. Arbetet styrs dock inte av ett löpande band eller en maskin (även om tekniska hjälpmedel såsom respiratorer kan finnas med i bilden) eller av en övervakande arbetsledare. I stället bestäms insatserna i hög grad av den anhöriges behov av tillsyn och hjälp. De fysiska restriktionerna är då inte det mest karakteristiska utan vad som sker på det psykologiska planet. Att vara bunden till en vårdperson kan innebära svårigheter att lämna denne i fysisk mening men framför allt att ständigt vara oroad och inte kunna släppa honom/henne ur sina tankar.

Bundenhet förekommer givetvis även bland annan vårdpersonal än anhörigvårdare, men det finns en grundläggande skillnad mellan dessa båda kategorier. Annan vårdpersonal har bestämda arbetstider och en rätt klar uppdelning mellan arbetstid och fritid. För anhörigvårdarna gäller sällan denna uppdelning $i$ tid.

Det finns också positiva faktorer som torde vara väsentliga för anhörigvårdares möjligheter att i sitt arbete känna glädje, stimulans och tillfredsställelse. I den sociologiska litteraturen har man framhållit betydelsen av sociala belöningar och socialt stöd i arbetslivet (se t.ex. Etzioni 1961, 1966, bl.a. s. 57-58, 79-80; Herzberg m.fl. 1957; House 1981; Johnson 1986; Karasek och Theorell 1990, särskilt s. 68-71; Vroom 1964). Dessa begrepp är inte alltid så väl definierade, men de inbegriper ofta sådant som respekt, uppmuntran och uppskattning. Sociala belöningar och socialt stöd antas kunna öka arbetstillfredsställelsen eller göra det lättare för arbetande att hantera stress vilket i sin tur kan förväntas ha en gynnsam effekt på arbetstillfredsställelsen.

I denna uppsats kommer vi att undersöka om och i vilken utsträckning en typ av socialt stöd, nämligen uppskattning från omgivningen, bidrar till de kommunalt anställda anhörigvårdarnas arbetsglädje. Det kanske till och med kan vara så att uppskattningen inverkar mer positivt på anhörigvårdarnas känslor av glädje, stimulans och tillfredsställelse än vad upplevelserna av bundenhet inverkar negativt.

\section{Undersökningens beroende och oberoende variabler}

Vi ska nu presentera våra centrala variabler och hur de har operationaliserats. Låt oss börja med de beroende variablerna. I materialet finns en del indikatorer på positiva känslor som anhörigvårdare kan uppleva $\mathrm{i}$ sitt arbete. Respondenterna ombads bl.a. ange hur ofta de ansåg sig känna glädje, stimulans respektive tillfredsställelse $i$ arbetet med att vårda/hjälpa en anhörig. Svarsalter- 
nativen var "alltid", "ofta", "sällan" och "aldrigu. Andelen som svarat "alltid" eller "ofta" redovisas i tabell 1. Till saken hör att ganska många respondenter valde att inte besvara den ena eller den andra delfrågan. Internbortfallet varierar mellan 17 och 24 procent för de tre delfrågorna och det högsta bortfallet gäller den om stimulans $i$ arbetet vilket förmodligen sammanhänger med att uttrycket "stimulans" torde vara svårt att förknippa med anhörigvård.

De procenttal som redovisas i tabell 1 är beräknade på ett bastal som bara inkluderar dem som svarat på respektive fråga. Resultaten bör mot bakgrund av det stora internbortfallet tolkas med viss försiktighet. Det kan också noteras att det bland dem som inte svarat finns en stark överrepresentation av äldre.

Som vi ser svarade nästan åtta av tio att de alltid eller ofta känner glädje - och kvinnor så i större utsträckning än män. Däremot var det mindre än 60 procent som påstod sig alltid eller ofta känna stimulans. På denna punkt finns ingen nämnvärd könsskillnad. Den tredje delfrågan avsåg tillfredsställelse och där utgör andelen svar registrerade för kategorierna walltid» och noftau knappt tre fjärdedelar. Återigen finner vi en viss skillnad mellan könen och den går åt samma håll som beträffande frågan om hur ofta man känner glädje. Det är återigen kvinnorna som i större utsträckning står för en positiv bedömning.

Därmed kan vi övergå till de variabler som förhoppningsvis kan bidra till att förklara varför anhörigvårdare upplever glädje, stimulans och tillfredsställelse i sitt arbete. Vad vi då i första hand ska uppmärksamma är bundenhet och uppskattning, men även en del andra variabler kommer att ingå $\mathrm{i}$ analysen.

Bundenhet mättes i vår empiriska undersökning med hjälp av fyra olika frågor. En handlade om huruvida anhörigvårdare ansåg sig kunna lämna sin anhörige för längre eller kortare tid utan tillsyn. Den andra frågan gällde direkt hur ofta man som anhörigvårdare upplever bundenhet. För det tredje frågades om man någon gång kunde känna sig helt ledig och för det fjärde om man vid faktisk ledighet kunde koppla av utan att oroa sig för den anhörige. En klar majoritet av de anställda anhörigvårdarna företedde klara tecken på bundenhet på samtliga dessa punkter vilket kan utläsas av tabell 2. Även i denna tabell är procenttalen beräknade på bastal som bara inkluderar dem som besvarat respektive fråga (bortfallet var dock betydligt mindre här: mellan 1 och 9 procent).

\begin{tabular}{|c|c|c|c|}
\hline & Kvinnor & Män & Totalt \\
\hline Känner alltid eller ofta glädje & 80 & 74 & 79 \\
\hline Känner alltid eller ofta stimulans & 58 & 57 & 58 \\
\hline Känner alltid eller ofta tillfredsställelse & 74 & 70 & 73 \\
\hline
\end{tabular}


Uppskattning har i enkäten fångats med hjälp av två frågor och de väsentliga resultaten redovisas också i tabell 2. I bastalen ingår, precis som beträffande bundenhet, bara de som svarat (bortfallet utgjorde 15 respektive 7 procent). Den första frågan gäller uppskattning i allmänhet och den var formulerad i samma stil som frågorna i tabell 1 . Individerna fick ta ställning till hur ofta de ansåg sig känna uppskattning och som vi ser svarade tre fjärdedelar att de alltid eller ofta gjorde det. Än en gång stod kvinnorna för en större andel positiva svar.

Den andra frågan var formulerad på följande sätt: „Anser du att samhället uppskattar den insats du gör så som den förtjänar att uppskattas? «. Svarsalternativen var ija, i hög grad", "ja, i viss mån"; "nej, knappast" och "nej, inte allsw. Som framgår av tabellen var det drygt 40 procent som besvarade frågan positivt. Skillnaden mellan kvinnor och män är liten.

Vi kommer vidare att undersöka betydelsen av de tre variabler som i föregående arti- kel visade sig ha viss betydelse för upplevelsen av bundenhet och som handlar om interaktionen mellan anhörigvårdarna och deras vårdpersoner samt omgivningen $\mathrm{i}$ övrigt. Den första av dessa gäller krav från vårdpersonernas sida på att just deras anhörigvårdare ska finnas tillgänglig. Nästa variabel avser svårigheten att säga nej när vårdpersonen vill ha hjälp med något som han eller hon egentligen skulle kunna klara själv. Slut- ligen ingår en fråga som syftar till att mäta hur lätt eller svårt anhörigvårdarna upplever sig ha att lita på andras omsorg. Samtliga dessa oberoende variabler kan vara relaterade till möjligheterna att uppleva glädje, stimulans och tillfredsställelse $i$ arbetet som anhörigvårdare.

I den empiriska analysen kommer även en rad andra faktorer att ingå. Vi föreställer oss att den hjälp man har eller saknar kan ha betydelse. Längden på den arbetstid man får betalt för kan tänkas spela en viss roll för upplevelsen av glädje, stimulans och tillfredsställelse. Materialet inkluderar vidare

\section{Tabell 2}

\section{Indikatorer på bundenhet i enkät till anställda anhörigvårdare 1993. Procent.}

Säger sig inte alls eller bara kortare stunder kunna lämna sin anhörige utan att det finns någon annan hos honom/henne

Uppger sig alltid eller ofta känna bundenhet

\begin{tabular}{ccc} 
Kvinnor & Män & Totalt \\
\hline & & \\
60 & 60 & 60 \\
74 & 69 & 73 \\
63 & 74 & 64 \\
60 & 63 & 60 \\
75 & 72 & 75 \\
42 & 41 & 42
\end{tabular}

Svarar nej på frågan om man någon gång kan känna sig helt ledig från arbetet som anhörigvårdare

Uppger sig vid ledighet sällan eller aldrig kunna koppla av utan att oroa sig för sin anhörige

Känner alltid eller ofta uppskattning för sina insatser för den anhörige

\begin{tabular}{ccc} 
Kvinnor & Män & Totalt \\
\hline & & \\
60 & 60 & 60 \\
74 & 69 & 73 \\
63 & 74 & 64 \\
60 & 63 & 60 \\
75 & 72 & 75 \\
42 & 41 & 42
\end{tabular}

Anser sig i hög grad eller viss mån få uppskattning från samhället 
uppgifter om huruvida man utöver den ekonomiska ersättningen har annan hjälp från samhället (hemtjänst, dagvård m.m.) och om man har privat hjälp. Dessa variabler kan också sägas representera olika former av socialt stöd. Även om ingen av dem spelade särskilt stor roll för upplevelsen av bundenhet vill vi pröva dem igen. Vad som däremot gav utslag var om man ansåg sig behöva mer hjälp av kommunen. Anhörigvårdare med icke tillgodosedda hjälpbehov upplevde bundenhet $\mathrm{i}$ betydligt större utsträckning än andra och kanske har denna variabel också betydelse för deras möjligheter att uppleva glädje, stimulans och tillfredsställelse i sitt arbete.

En annan faktor som ska inkluderas är typ av relation mellan vårdgivare och vårdtagare. Undersökningen urskiljer fyra typer av relationer: maka/e-make/a, föräldrarbarn, barn-föräldrar samt annan relation. Det är väsentligt att hålla i minnet att det finns både köns- och åldersmässiga skillnader mellan dessa fyra kategorier. Flertalet av de män som är anhörigvårdare sköter sin maka och flertalet av de anhörigvårdare som är gifta eller sammanboende med den de vårdar är äldre. Vi kommer genomgående att kontrollera för ålder och kön i de analyser vi gör. Däremot är vi inte beredda att i förväg formulera några antaganden om vad kön och ålder kan betyda.

En väsentlig omständighet vid anhörigvård är boende. I vårt material görs en åtskillnad mellan fyra kategorier: de som bor ihop med vårdtagaren, de som bor i samma fastighet, de som bor inom gångavstånd och de som bor längre bort. Boendeform kan sägas vara en objektiv indikator på bundenhet. I vår förra artikel framgick också att de som bodde i ihop med sin vårdperson i flera avseenden upplevde sig betydligt mera bundna än de som inte gjorde det. Här visar det sig emellertid att boende inte har den betydelse som vi förväntade oss. Variabeln ingår därför inte i den analys av arbetsglädje och arbetstillfredsställelse som följer.

\section{Analys: arbetsglädjens korrelat}

Datamaterialet har analyserats med hjälp av logistisk regression som är en användbar metod när man arbetar med dikotoma beroende variabler. Tabell 3 anger oddskvoter för olika kategorier, dvs. "risken" att en viss kategori ska ha svarat på ett visst sätt jämfört med motsvarande risk för en referenskategori, samt huruvida förekommande skillnader är statistiskt signifikanta.

Till att börja med kan vi konstatera att kön och ålder inte ger några som helst signifikanta utslag. Vad som däremot har viss betydelse är typ av relation, men det finns bara ett enda signifikant resultat att redovisa. Föräldrar som vårdar barn har i betydligt större utsträckning än andra svarat att de alltid eller ofta känner glädje. På de båda övriga beroende variablerna har föräldrarna också högre tal än referenskategorin, men utfallen är inte signifikanta.

Arbetstid som anhörigvårdare är en annan variabel där vi finner ett signifikant samband. De som har heltid har i större utsträckning än andra uppgett sig alltid eller ofta känna stimulans i sitt arbete. Tendensen går i huvudsak i samma riktning för de två andra beroende variablerna, men det blir inga signifikanta utslag. Ändå förefaller det vara en rimlig slutsats att arbetet som 


\section{Tabell 3}

Faktorer relaterade till olika mått på arbetsglädje. Enkät till anställda anhörigvårdare 1993. Logistisk regression. Exp. (B).

Anhörigvårdarens kön

Känner alltid

Känner alltid

Känner alltid eller eller ofta glädje eller ofta stimulans

ofta tillfredsställelse

Kvinna

Man (ref.)

Anhörigvårdarens ålder

$-34$

$35-44$

$45-54$

$55-64$

65- (ref.)

Relation

Makela-maka/e

Bam-förälder

Förälder-bam

Övriga (ref.)

Arbetstid som anhörigvårdare

Heltid

Lång deltid

Kort deltid (ref.)

Behov av hjälp från samhället

Behöver mer hjälp

Behöver ej hjälp (ref.)

Upplever bundenhet

Alltid eller ofta

Sällan eller aldrig (ref.)

Förmåga att koppla av vid ledighet

Sällan eller aldrig

Alltid eller ofta (ref.)

Svårighet att säga nej då vårdpersonen vill ha hjälp med något som han/hon egentligen skulle klara själv

Mycket eller ganska svårt

Mycket eller ganska lätt (ref.)

Känner uppskattning för sitt arbete

Alltid eller ofta

Sällan eller aldrig (ref.)

Signifikansnivåer: ${ }^{*}=p<0,05 ;$ ** $=p<0,01$; ${ }^{*} * * * 0<0,001$.

\section{3}

1.0

0.9

1.0

0.9

1.0

0.9

0.9

1.1

I.I

0.5

0.9

0.9

1.0

***

0.8

1.0

$2.6 * *$

1.0

1.3

1.0

1.0

0.8

1.0

$0.4^{* * * *}$

1.0

$0.6 *$

1.0

0.8

1.0

$0.7 *$

1.0

$0.6 * *$

1.0

$8.9 * * *$

$5.5 * * *$

$6.7^{* * * *}$

1.0

1.0 anhörigvårdare lättare upplevs positivt om man får betalt för en heltidsinsats.

Hjälpbehov är en annan och mer betydel- sefull variabel. Här finner vi klara samband med hur ofta man känner stimulans respektive tillfredsställelse i sitt arbete. Om man 
inte anser sig få tillräcklig hjälp så är risken betydligt större att man inte känner vare sig stimulans eller tillfredsställelse. Tendensen i materialet är densamma vad gäller upplevelsen av glädje, men utfallet på den variabeln är inte statistiskt signifikant. Vi kan också konstatera att samhällelig hjälp utöver den ekonomiska ersättningen och privat hjälp inte uppvisar några signifikanta samband alls med någon av de tre beroende variablerna.

Man bör tänka på att upplevt hjälpbehov handlar om flera olika dimensioner. Vårdarbetet kan vara fysiskt påfrestande så att anhörigvårdaren av det skälet behöver hjälp, exempelvis med tunga lyft. Det är ibland psykiskt påfrestande vilket medför andra stödbehov. Den som har ett ständigt vårdansvar har kanske också svårigheter att få sova ostört på natten och behöver avlösning för att kunna göra det. En annan viktig aspekt är vilka och hur starka krav vårdgivaren ställer på att få förbättringar för sin anhörige, t.ex. i form av rehabilitering, och hur aktiv vårdtagaren själv är i dessa avseenden - samt hur kommunen möter de krav som ställs.

Därmed kommer vi in på bundenhetsvariablerna. Två av de fyra som ingår i tabell 2 har betydelse och bara dessa två är inkluderade i den analys som redovisas i tabell 3 . De anhörigvårdare som sagt sig alltid eller ofta uppleva bundenhet har betydligt svårare än andra att i sitt arbete känna glädje, stimulans och tillfredsställelse (sambandet för den senare dimensionen är dock svagare). För den variabel som mäter huruvida man har svårt att vid ledighet koppla av utan att oroa sig för sin anhörige pekar resultaten $i$ samma riktning, men de är signifikanta en- dast för två av de beroende variablerna.

En av de variabler som syftar till att fånga något av samspelet mellan anhörigvårdarna och deras vårdpersoner är signifikant. Den gäller huruvida man som anhörigvårdare har svårt att säga nej då vårdpersonen vill ha hjälp med något som denne egentligen borde klara av själv. De som upplever sig ha sådana svårigheter verkar också i mindre utsträckning kunna känna stimulans och tillfredsställelse i sitt arbete.

Till sist har vi den variabel som förefaller ha störst betydelse av alla, nämligen uppskattning. Det är emellertid bara den ena av de två variablerna från tabell 2 som ger signifikanta utslag. Att som anhörigvårdare erfara att man alltid eller ofta får uppskattning innebär att det blir mycket lättare att känna såväl glädje som stimulans och tillfredsställelse i arbetet. Däremot tycks det sakna betydelse om man upplever sig få uppskattning från samhällets sida (men det sammanhänger med att denna variabel delvis absorberas av den förstnämnda - se vidare nedan).

\section{Uppskattningens bestämningsfaktorer}

Eftersom uppskattning framstår som något så viktigt för anhörigvårdarnas upplevelser av glädje, stimulans och tillfredsställelse i sitt arbete vill vi driva analysen ett steg vidare. Ambitionen är att identifiera förhållanden som samvarierar med denna centrala faktor. I det följande inkluderas även variabeln uppskattning från samhället trots att den inte gett några signifikanta resultat i den tidigare analysen - den är dock korrelerad med variabeln uppskattning i allmänhet och tycks sna- 
rast utgöra en delaspekt av denna. Vissa oberoende variabler är de samma som tidigare. Förutom kön och ålder ingår typ av relation, boende, samhällelig hjälp utöver ekonomisk ersättning och privat hjälp.

Därutöver har vi tagit med två andra variabler som eventuellt har betydelse. Den ena gäller anställningens varaktighet. Man kan tänka sig att anhörigvårdare till en början möter rätt stor uppskattning från sin omgivning men att den efter hand avtar. Vi har här dragit en skiljelinje vid två år eftersom vi tidigare funnit att det verkar gå en kritisk gräns ungefär där. Den andra variabeln fångar huruvida anhörigvårdarnas ekonomi - sedan anställningen påbörjades förbättrats, försämrats eller är ungefär densamma som förut. Denna materiella dimension kan antas vara ganska betydelsefull även om uppskattning i och för sig är något icke-materiellt. Ekonomisk belöning eller kompensation kan ju tolkas som uttryck för uppskattning - $i$ det här fallet främst från samhällets sida.

Analysen av vilka faktorer som är relaterade till känslan av uppskattning redovisas i tabell 4. Vi kan till att börja med observera att det inte föreligger några skillnader av betydelse mellan män och kvinnor. Däremot får vi vissa sådana resultat beträffande ålder. När det gäller uppskattning i allmänhet är åldersvariabeln inte signifikant även om talet för de allra yngsta är nästan en och en halv gånger referenskategorins. I fråga om uppskattning från samhället finns emellertid signifikanta resultat att redovisa. Anhörigvårdarna $i$ ålderskategorierna 35-44 år och 45-54 år har i mindre utsträckning än referenskategorin angett att de känner sig uppskattade av samhället. Utfallet för de yngsta är inte signifikant men pekar i samma riktning. Dessa resultat kan vara uttryck för att de medelålders eller relativt unga förväntar sig mer av kommunen än de äldre.

När det gäller typ av relation blir det beträffande uppskattning i allmänhet ett tydligt utslag som har att göra med att en kategori starkt avviker från de övriga: barn som tar hand om sina föräldrar. Det är uppenbarligen lättare att i den situationen röna uppskattning för sitt arbete som anhörigvårdare. Samtidigt har den kategorin i mindre utsträckning uppgett sig känna uppskattning från samhällets sida. På den senare punkten gäller detsamma, fastän ännu tydligare, för föräldrar som vårdar sina barn.

Till skillnad från vad som var fallet $i$ analysen av glädje, stimulans och tillfredsställelse $i$ arbetet ger boendevariabeln här i alla fall ett signifikant resultat. Anhörigvårdare som bor ihop med sin vårdperson upplever i mindre utsträckning än referenskategorin uppskattning från omgivningen. Detta kan sammanhänga med att de som bor ihop i hög grad är hänvisade till varandra och har mer begränsade kontakter med omvärlden. Det handlar här framför allt om personer som är gifta eller sammanboende med varandra. Vårdåtagandet är i dessa fall mer av en självklarhet vilket sannolikt ger mindre av uppskattning såväl från den som erhåller hjälpen som från andra.

Boendeform uppvisar ingen signifikant samvariation med uppskattning från samhället. Det gör däremot de fyra sista oberoende variablerna i tabell 4 och dessa sakniar samtidigt betydelse för variabeln uppskattning i allmänhet. Den första är anställningens varaktighet och som vi ser blir utfallet starkt signifikant. Anhörigvårdare med 
längre anställningstid (här lika med två år eller mer) har i markant högre grad än de med kortare anställningstid svarat att de inte uppskattas av samhället för sitt arbete.
Som betald vårdgivare tycks man efter hand allt mer känna att ens insatser inte röner uppskattning i samhällsapparaten.

Huruvida denna förändring beror på att

\section{Tabell 4}

Faktorer relaterade till anställda anhörigvårdares upplevelser av uppskattning. Enkät 1993. Logistisk regression. Exp. (B).

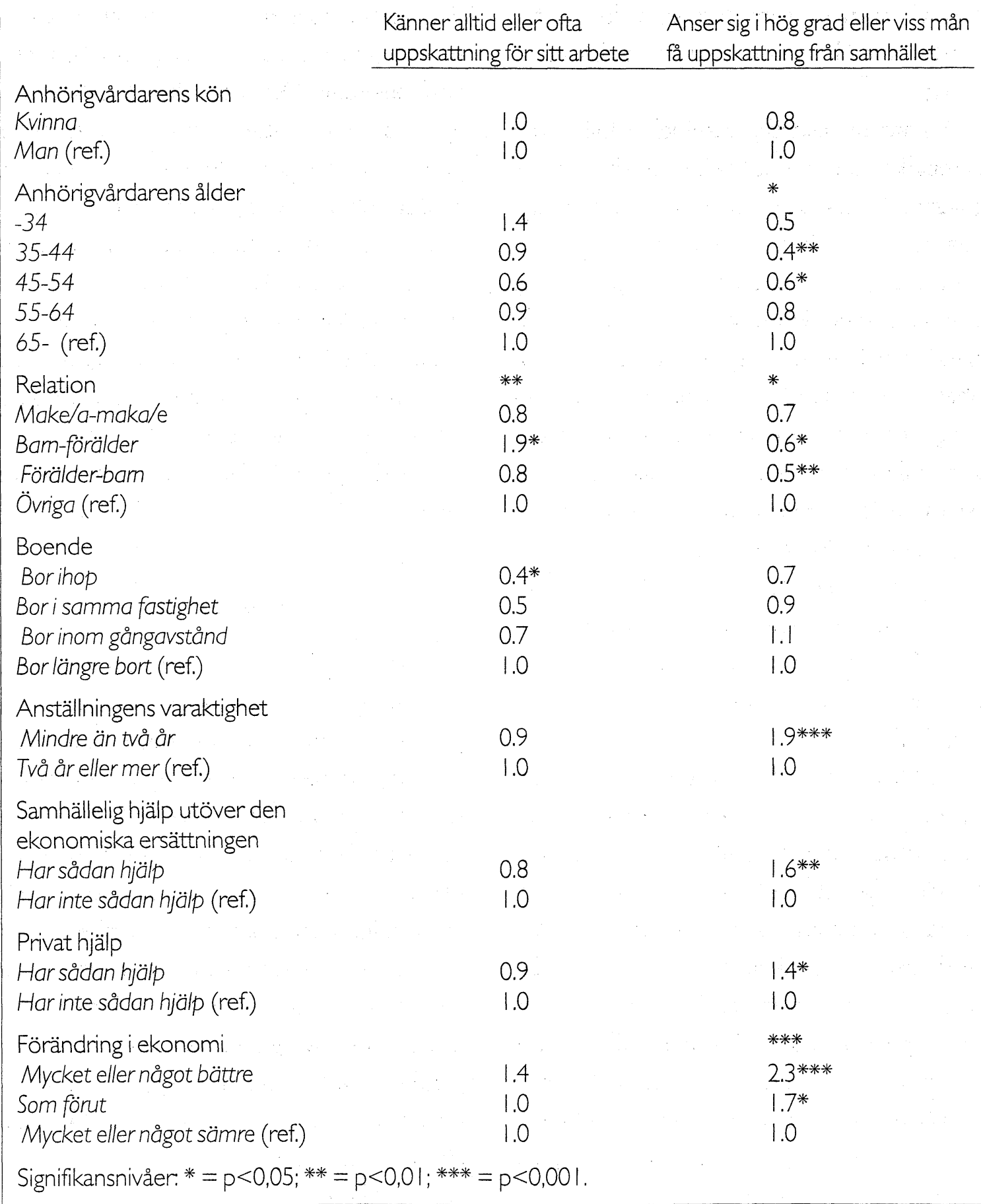


kommunens engagemang minskar eller på att anhörigvårdarnas insatser blir mer omfattande eller på något annat har vi inte möjlighet att uttala oss om här. Antagandet att arbetet blir tyngre med tiden får emellertid visst stöd i intervjuerna och även i de brev och kommentarer som ofta medföljde enkätsvaren. Där framkom ibland att antalet timmar man en gång fått sig tilldelad för vården inte ökat $i$ takt med att vårdinsatsen vuxit.

En annan väsentlig variabel är hjälp från samhället utöver den ekonomiska ersättningen. Att ha sådan hjälp (hemtjänst, dagvård m.m.) är direkt relaterat till i vilken utsträckning man upplever sig få uppskattning från samhället. Som vi kan se blir det ett liknande om än något svagare resultat för variabeln privat hjälp. Det senare är anmärkningsvärt. Förekomsten av privat hjälp tycks göra anhörigvårdarna mer benägna att uppge att de får uppskattning från samhället men har samtidigt inte alls den effekten på variabeln uppskattning i allmänhet. En förklaring till detta kan möjligen vara att man inkluderar den privata hjälpen från släktingar, grannar och vänner under kategorin "samhället».

Vid hemtjänst, dagvård eller liknande insatser från kommunen kommer någon eller några utomstående att inbegripas i vårdarbetet vilket betyder att man som anhörigvårdare får andra människor att diskutera vården med. Det bör också bli lättare att vara vårdare om man får en instans att dela ansvaret med, speciellt om vårdtagaren håller på att bli sämre. Att bli medveten om möjligheten att vården successivt kan överföras till kommunen bidrar troligen till att skapa trygghet och minska oron inför framtiden.
Slutligen finner vi att vad som hänt med anhörigvårdarnas ekonomi sedan deras arbete blev betalt också är synnerligen betydelsefullt. För dem som upplever sig ha fătt mycket eller något förbättrad ekonomi gäller att siffrorna i tabellen kraftigt överstiger referenskategorins. Förbättrad ekonomi verkar med andra ord uppfattas som uttryck för uppskattning trots att uppskattning som påpekats primärt är en fråga om icke-materiell belöning. Detta resultat framkommer även i de kommentarer som respondenterna gjort i enkäten och i de intervjuer med anställda anhörigvårdare som vi genomfört.

I detta sammanhang ska poängteras att många av de anställda anhörigvårdarna har utfört vårdarbetet obetalt innan de blev anställda. Även om lönen ofta är blygsam har ekonomin i och med anställningen förbättrats. Det har med andra ord inte alltid krävts så mycket för att man ska kunna tala om en förbättring.

\section{Avslutning}

Anhörigvården har ett janusansikte med både mörka och ljusa sidor. Vår studie av kommunalt anställda anhörigvårdare visar att många upplever bundenhet och svårigheter att koppla av från sina uppgifter, men också att deras arbete rymmer påtagligt positiva inslag - av glädje, stimulans och tillfredsställelse. Känslan av bundenhet är likväl $\mathrm{i}$ hög grad bestämmande och begränsande för i vad mån de positiva sidorna framträder. I det avseendet tycks det finnas en parallell med en del av de jobb som förekommer $\mathrm{i}$ industrin även om man ska vara försiktig med att jämställa anhörigvård med sådana arbeten. 
Det finns emellertid en annan dimension som förefaller vara ännu viktigare, nämligen huruvida man känner uppskattning för det man uträttar som anhörigvårdare. De som får den sortens belöningar upplever i större utsträckning de positiva sidorna vi talar om. Det finns också en del andra faktorer som har betydelse för upplevelsen av glädje, stimulans och tillfredsställelse, men uppskattning å ena sidan och (frånvaron av) bundenhet å den andra verkar vara de mest väsentliga.

Uppskattning är som sagt en nyckelfaktor för anhörigvårdarna. Denna typ av socialt stöd kan komma från olika håll: från vårdpersonen själv, från andra anhöriga, från grannar och vänner och från "samhället». Den senare kategorin kan tyckas abstrakt, men i konkreta termer verkar det framför allt handla om de pekuniära belöningar som är förknippade med anställning som anhörigvårdare. Det är i stor utsträckning de som upplever att deras ekonomi har förbättrats som också säger att de känner sig uppskattade av samhället. Man kan uttrycka det så att kommunens speciella sätt att visa sin erkänsla ligger $\mathrm{i}$ att ge vårdgivarna en rimlig betalning.

Anhörigvårdare tycks behöva en stödjande omgivning som genom olika insatser kan hjälpa till att mildra bundenheten och som kan visa sin uppskattning. De informella sociala nätverk som de flesta har omkring sig är kanske då det man i första hand tänker på. I en del av intervjuerna och enkätsvaren framträder emellertid bilden av en tilltagande isolering genom den anhöriges sjukdom/ handikapp. Även om man från början hade ett starkt informellt nätverk tenderade detta av olika skäl att tunnas ut. För att komma till rätta med anhörigvårdens problem med bundenhet tycks det med andra ord också behövas andra lösningar än vänskaps- och grannkontakter.

Bundenhet kan vara en destruktiv kraft och om man vill att anhörigvårdarnas arbete ska fungera väl för alla inblandade är det viktigt att försöka minska eller lindra den. Här finns många olika möjligheter till hjälp och kommunen är en central aktör i den stödstruktur som behövs för att anhörigvården ska kunna bedrivas under gynnsamma betingelser. Det är av största vikt att den kan erbjuda vårdgivarna och vårdtagarna konkret hjälp i olika former - rehabilitering, habilitering, avlösning eller liknande - och en lön som är både ett erkännande för en viktig arbetsinsats och försörjning för dem som till följd av vårdarbetet inte kan försörja sig på annat sätt. I detta ligger det bästa beviset på uppskattning som kommunen kan ge.

\section{Summary \\ Work Satisfaction among People Employed to Care for Their Relatives}

From a survey of a sample (about 1200 respondents) of municipally employed persons caring for their elderly or disabled relatives it was shown, in a previous article, that these care-givers often feel tied down in their work. In contrast, the present article deals with positive aspects of this work, i.e., with work satisfaction. It turns out that the care-givers' experience of lack of freedom is important in order to explain why they are 
dissatisfied with their situation. However, the most important factor behind work satisfaction appears to be the appreciation expressed by people in the immediate environment. And it is also demonstrated that the care-givers' feelings of being appreciated for their work are related to how their economic conditions have been affected since they started to receive reimbursment from the local authorities.

\section{Referenser}

Aronsson, Gunnar m.fl. (1995): Kvalitet genom in flytande. Om förändring och utveckling i hemtjänsten. Arbetslivsinstitutet, Stockholm.

Blauner, Robert (1964): Alienation and Freedom. Chicago Press, Chicago.

Eliasson, Rosmari (1996): Omsorgens skiftningar. Begreppet, vardagen, politiken, forskningen. Studentlitteratur, Lund.

Eliasson, Rosmari (red.)(1992): Egenheter och allmänheter. En antologi om omsorg och omsorgens villkor. Arkiv, Lund.

Eliasson, Rosmari m.fl. (1984): Att arbeta inom äldreomsorgen, att vara pensionär och att möta varandra. FoU-byrån, Stockholms socialförvaltning. FoU-rapport nr 3.

Etzioni, Amitai (1961): A Comparative Analysis of Complex Organizations. On Power, Involvement, and Their Correlates. The Free Press, New York.

Etzioni, Amitai (1964): Moderna organisationer. Aldus/Bonniers, Stockholm.

Evertsson, Lars (1995): „Vårdbiträden och undersköterskor - en ouppmärksammad professionshistoriau. I Johansson, Stina (red.): Sjukhus och hem som arbetsplats. Omsorgsyrken i Norge, Sverige och Finland. Bonniers, Stockholm.

Furåker, Bengt och Mossberg, Ann-Britt (1997): "Vårdansvar och bundenhet. Om anställda anhörigvårdare i Sverige«. Socialvetenskaplig tidskriftnr 1 .

Gardell, Bertil (1971): Produktionsteknik och arbetsglädje. En socialpsykologisk studie av industriellt arbete. Personaladministrativa rådet.

Gardell, Bertil (1976): Arbetsinnehall och livskvalitet. Prisma, Stockholm.

Gardell, Bertil och Gustafsson, Rolf A. (1979):
Sjukvård på löpande band. Prisma. Stockholm. Herzberg, Frederick m.fl. (1957): Job Attitudes. Review of Research and Opinion. Psychological Service of Pittsburgh, Pittsburgh, Penn.

House, James S. (1981): Work Stress and Social Support. Addison and Wesley, Reading, Mass. Johnson, Jeff V. (1986): The Impact of Workplace Social Support, Job Demands and Work Control upon Cardiovascular Disease in Sweden. Ph.D. diss. Johns Hopkins University. Distr. genom psykologiska institutionen, Stockholms universitet.

Karasek, Robert och Theorell, Thöres (1990): Healthy Work. Stress, Productivity and the Reconstruction of Working Life. Basic Books, New York.

Korpi, Walter (1978): Arbetarklassen i välfärdskapitalismen. Arbete, fackförening och politiki Sverige. Prisma, Stockholm.

Orban, Pal (1995): „Sjukvården och sjukhuspersonalen«. I Svensson, Lennart och Orban, Pal (red.): Människan i tjänstesamhället. Studentlitteratur, Lund.

Szebehely, Marta (1995). Vardagens organisering. Omvårdbiträden och gamla i hemtjänsten. Arkiv förlag, Lund (akademisk avhandling).

Topor, Alain (1988): Hemtjänsten, människor och psykiska problem. Värdbiträdenas samlade tystnader. Esselte Studium, Stockholm.

Ungerson, Clare (1990): „The Language of Care: Crossing the Boundariesw. I Ungerson, Clare (ed.): Gender and Caring. Work and Welfare in Britain and Scandinavia. Harvester Wheatsheaf, New York.

Vroom, Victor, H (1964): Work and Motivation. John Wiley \& Sons, New York. 